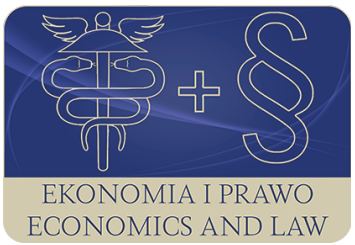

EKONOMIA I PRAWO. ECONOMICS AND LAW

Volume 18, Issue 1, March 2019

p-ISSN 1898-2255, e-ISSN 2392-1625

www.economicsandlaw.pl

ORIGINAL ARTICLE

received 02.01.2018; revised 17.07.2018; accepted 31.03.2019

Citation: Klonowska, A. (2019). Barriers for effectiveness of fiscal policy: the case of Poland Ekonomia

i Prawo. Economics and Law, 18(1): 29-45.

doi:10.12775/EiP.2019.003.

\title{
Barriers for effectiveness of fiscal policy: the case of Poland
}

\author{
ALINA KLONOWSKA \\ Cracow University of Economics, Faculty of Finance and Law, Department of Finance, \\ ul. Rakowicka 27, 31-510 Kraków, Poland \\ ఐklonowsa@uek.krakow.pl \\ (D) orcid.org/0000-0003-4627-8668
}

\begin{abstract}
Motivation: It is commonly known that the public authorities responsible for the implementation of fiscal policy aim to achieve social and economic objectives. Nevertheless, as in the case of the private sector, there are factors that can limit the achievement of these goals. Retrospective analysis of the policy conducted by fiscal authorities in Poland, in the period prior to and post-crisis, proves the existence of numerous reasons that determine the particular effectiveness of the policy. This in turn leads to many interesting evaluative judgments. The essence and main objectives of fiscal policy will be defined on the basis of the literature review. Furthermore, an attempt will be made to answer

the question what effective fiscal policy means, what factors determine it and what measures can evaluate this effectiveness. Empirical part of the paper will present shaping of the macroeconomic indicators. Further, it will concern the recognition of factors that affect the achievement of the objectives on the basis of statistical data analysis. The summary will include assessment of the rationality and verification of the validity of fiscal decisions taken by the authorities.

Aim: The main goal of the article is to recognize and assess the factors affecting the achievement of the objectives of fiscal policy in Poland. This aim is accompanied by the following hypothesis; adopted system solutions by the authorities make it impossible to conduct effective fiscal policy in Poland.

Results: The anticipated results will be visible in the form of highlighting the factors which were characterized by both the negative and positive impact on the achievement of the objectives of fiscal policy in Poland. It should consequently contribute to considering possible system changes in the future.
\end{abstract}


Keywords: fiscal policy; public revenues; public expenditures; sustainability of public finance JEL: H20; H26; H50; H60

\section{Introduction}

It is commonly known that the public authorities responsible for the implementation of fiscal policy aim to achieve social and economic objectives. Nevertheless, as in the case of the private sector, there are factors that can limit the achievement of these goals. Retrospective analysis of the policy conducted by fiscal authorities in Poland in the period prior to and post-crisis, proves the existence of numerous reasons that determine the particular effectiveness of the policy. The main goal of the article is to recognize and assess the factors affecting the achievement of the objectives of fiscal policy in Poland. This aim is accompanied by the following hypothesis; adopted system solutions by the authorities make it impossible to conduct effective fiscal policy in Poland.

The article consists of the Introduction, five numbered parts, Conclusions and policy implications. The essence and main objectives of fiscal policy will be defined on the basis of the literature review. Furthermore, an attempt will be made to answer the question what effective fiscal policy means, what factors determine it and what measures can evaluate this effectiveness. Empirical part of the paper will present shaping of the macroeconomic indicators. Further, it will concern the recognition of factors that affect the achievement of the objectives on the basis of statistical data analysis.

The summary will include assessment of the rationality and verification of the validity of fiscal decisions taken by the authorities.

\section{The significance of the effectiveness of fiscal policy - literature review}

Fiscal policy is one of the components of financial policy or even socio-economic policy. The concept of fiscal policy should be understood as pursuing socio-economic policy aims. In this context the question should be asked whether talking about fiscal effectiveness is proper and needed. This topic has been described in the literature and has occupied a central role during debates on fiscal policy for years (Kofuji, 1984; Konopczyński, 2012; Krajewski, 2015). Some argue that fiscal policy (under specified conditions) remains a powerful tool within macroeconomic policy (Arestis \& Sawyer, 2004). In the time of the recent crisis, fiscal policy and its influence on macroeconomic stability has become a particular point of interest (Corsetti \& Müller, 2008). Some pay attention to its importance in achieving fiscal stability of the country in the perspective of future shocks (Auerbach \& Gorodnichenko, 2017). The more that as Gaspar (2016) wrote "public finance and fiscal policy are in search of a new paradigm and threefold classification of public finance functions-allocation, distribution, and stabilization - is showing signs of wear and tear, after a half 
century'. So far, in the literature on the subject, the approach prevails focusing on the analysis of the impact of fiscal policy on the economy, often presented in opposition to monetary policy (Carnot, 2014; Chakraborty, 2016; Christ, 1979; Friedman \& Heller, 1969). Therefore, the issue of the effectiveness of fiscal policy is most often interpreted from the point of view of macroeconomics (Hebous, 2010; Hemming et al., 2002; Seidman, 2003). As part of simple or complex economic models, the influence of discretionary decisions of fiscal authorities (within an expansive or restrictive policy) on the economic situation of the country is explained (Poindexter, 1976). To a lesser extent, the discussion is taken in the evaluation of the effectiveness of fiscal policy in achieving the fiscal objectives from the point of view of analyzing solutions already existing in the public finance system of the state. Meanwhile, as Stoian and Campeanu (2010) wrote the significance of fiscal effectiveness is connected with responsibility of policymakers at least for fiscal balance.

The review of literature proves that some researchers investigate the efficiency in the context of public expenditure only (Mandl et al., 2008). Others use a structural VAR analysis of real GDP, tax revenues, and public expenditures (Karaca \& Ugurlu, 2014; Kuttner \& Posen, 2002). Finally, the effectiveness of fiscal policy can be assessed on the basis of observation of the macroeconomic indicators such as: GDP, inflation rate, unemployment rate, as well as budget balance or public debt.

The fiscal effectiveness can have different faces. But in general, the effectiveness of fiscal policy should be understood as fulfilment of legally regulated policy aims. Furthermore, it can mean satisfying public and social needs with maintaining high quality of public services.

The authorities accomplish two main aims:

- fiscal,

- non fiscal.

The first one relies on satisfying State demand for money through collecting taxes or taking loans. Whereas, among non fiscal aims there are inter alia (Owsiak, 2006, p. 361): aiming for high and steady economic growth and simultaneously the high rate of society wealth; maintaining low rate of unemployment; stabilizing prices within cooperation with monetary authorities; reducing the fluctuations of business cycle; reducing excessive income inequalities in society.

Achieving these aims depends on some aspects which are connected with the effectiveness of fiscal policy (Hemming et al., 2002). Amongst them there are at least: the way of public budget planning, the scale of redistribution of GDP, the structure of public expenditures, the size of grey economy etc.

\section{Methodology of research}

The research methods applied in the work will involve exploring, analysing and reasoning within the collected materials. For this purpose, the research 
methods: qualitative and quantitative will be used. Firstly, the research will be carried out based on literature studies. Quantitative methods will be based on the statistical analysis of data in the following categories:

- GDP, inflation, unemployment rate and employment indicator;

- tax revenues, tax gap;

- public expenditures;

- condition of public finances.

The adopted test period covers the years 2000-2016. However, due to limited access to the data, in some cases the analysis period has been shortened.

\section{Macroeconomic indicators}

Poland is one of the countries which after transformation became the European Union member in 2004. Since the accession, the condition of the economy has become much better compared to the period before our membership. It should be marked that undoubtedly good government decisions undertaken within fiscal policy played crucial role in providing such results. Macroeconomic indicators confirm this opinion.

\subsection{Pursuing non-fiscal aims}

Before the accession of Poland to the EU, the GDP rate was at the average level of 2\%. In the years 2004-2016, the average rate of economic growth in Poland oscillated around 4\% (the highest GDP growth occurred in 2007). It allowed to increase the country's wealth ratio. In 1995, GDP per capita (in PPS) fluctuated around $45 \%$ of the EU average, currently $69 \%$ (Eurostat, 2017).

The average rate of unemployment was comparable to the period before accession and was relatively high (14.4\%). What is the most important, the rate of unemployment characterizes with steadily downward trend since 2002 to 2008. After the crisis this rate is again on the path of decline. In 2015 the rate was $9.7 \%$. Ministry of Finance assumes to receive the unemployment rate below 8.5\% by 2020 (Ministerstwo Finansów, 2016b). Additionally, the rate of employment has been steadily rising, mainly after 2003. In 2015 this measure reached the highest level in comparison to the whole analysed period (62.9\%). In average the rate of employment was $56.9 \%$ and it was rather low in comparison to EU average which amounted to $64.1 \%$.

The transformation of the economy brought a high inflation which remained double-digit till 2000. From 2004 the average rate of the same measure oscillated about $2 \%$ and never again exceeded $10 \%$. In 2013, inflation remained significantly below the inflation target. A year later, the inflation rate was $0 \%$. In 2015 deflation occurred. In the whole period the average rate amounted to $2.9 \%$. It is slightly more than inflation target. Chart 1 presents data on shaping the main macroeconomic indicator reflecting achieving objectives within non fiscal aims. 
The role of fiscal policy comes down to the finding that Government can affect national economy and public finances. General analysis of macroeconomic situation proves relatively right direction of undertaken decisions within fiscal policy. But can the same policy effectiveness be achieved also in the fiscal area?

\subsection{Achieving fiscal aims}

Although macroeconomic situation was relatively stable, the financial situation was becoming worse. As a result of good economic condition only in 2007 there was a small surplus in public budget. While in 2002 and 2010 it reached the highest level in relation to GDP (almost 6\%). The average deficit amounted to $-3.3 \%$ GDP. It is slightly more than the criterion indicated in the Maastricht Treaty. Simultaneously, public debt remained at $42 \%$ of GDP until accession but after the change it rose to 53\% of GDP. In the whole period the average amount was at the level of $47.1 \%$ of GDP. Data concerning deficit budget and public debt is presented in chart 2 .

Taking into consideration the financial situation, it should be pointed out that although having achieved relatively good outcomes in subsequent years we can observe significant fluctuation of results.

\section{Factors affecting the effectiveness of fiscal policy}

Amongst many causes which can have various impact on accomplishing fiscal and non fiscal aims there are some extremely important. It is possible to mark some features which can be called 'weak points' of the system. They influence steadily and negatively the balance of public budget and in indirect way also other macroeconomic indicators.

The case of fiscal sustainability concerns mostly European countries, also Polish authorities. Likewise, achieving financial stability after fiscal crisis has become a priority of public authorities in all countries of the Community (Potrafke and Reischmann, 2015). This is further important mainly for fiscal capacity and primary deficits in the context of the intertemporal budget constraints. (Collard et al., 2015).

All in all, achieving fiscal stability is an expression of an effective fiscal policy. As far as measures taken for financial stability are part of the process of fiscal consolidation (European Commission, 2016a; Kickert, 2015). Usually on the one hand such activity brings benefits since it is connected with growing tax rates, broadening tax base, limiting the amount of public expenditures, implementing fiscal rules etc. (Barrios et. al., 2010). But on the other hand it doesn't meet with common societal acceptance. Żabiński (2010), observes that the mistakes made in the selection of the tools of fiscal policy entail significant risks. The Government in its role should cyclically provide some kind of research or recognition of the public system in the context of adopted solutions. 
Effective solutions can bring effective fiscal policy and in consequence public satisfaction.

\subsection{Public revenue side}

As in other European countries, taxes are the main source of public revenues in Poland. Starting from 2000, the share of tax revenues in public revenues has remained at the level of nearly 90\% (Ministry of Finance, 2000a-2015a). It is worth marking that in the early 90s of the twentieth century the reform of tax system was performed. The rules underlying the reformed tax system assumed the existence of a few types of taxes which will play the main role in gathering the public revenues. These include, among others: Value Added Tax, excise tax and income taxes.

Nowadays, tax system in Poland consists of two main groups of taxes: direct and indirect. Indirect taxes dominate in structure of tax revenues. In relation to GDP its share amounted 13\% in 2000-2014 while the share of direct taxes was $7 \%$, the third group was social security contributions with the share of almost 12\% (European Commission, 2016a, p. 150). Research emphasizes that if we pay attention to the relation of tax receipts to GDP, position of Poland is in the middle in comparison to other members of the Union (Eurostat, 2017).

The amount of public revenues changed gradually during more than a decade. The characteristic is lower share of public revenues in GDP (38.6\%) maintained since 2009. In the years 2000-2008 it was 40\% of GDP. In the whole period the rate of fiscalism in Poland was an average of 39\% GDP. Taking into consideration only taxes, their relation to GDP was about $20 \%$. As we can see, social contributions have significant impact on the level of fiscalism. The average rate of fiscalism is greater than 13 p.p. In addition to high rates of social insurance unchanged in the years 2010-2016 there was a low tax-free amount, which determined the relatively higher level of taxation.

Revenues were shaped in line with changes in GDP, except for 2004. In this year public revenues as well as tax revenues and social contributions decreased. Polish accession influenced the shape of public revenues. It was connected with changes within tax system and a new category of revenues such as transfers from the EU. Similarly, during the years 2009 and 2013 slight decline in observed categories was noted. As we know, it was a time of global crisis. Due to the recession, public revenues in the period 2004-2009 grew much more slowly than expenditures. The pace of their change in terms of annual average basis did not exceed $2.90 \%$. While in the years 2010-2015 the growth rate of public revenues amounted to 3.6\% (Eurostat, 2017). Changes within data on fiscalism in Poland is presented in chart 3.

Public revenue system should guarantee achieving fiscal aim. In this context we have to underline that general data concerning public revenues don't allow to assess the extent of tax losses. We can not forget that practice proves differences between planned and executed incomes observed every year. The 
statistical data show that the share of tax debts (taxes not paid on time) in GDP averaged almost 2\% in 2000-2015. In the years 2003 and 2013-2015 a rapid increase can be observed in this category. This was an average of $30 \%$ (previous year $=100$ ). Chart 4 presents data concerning amount of tax debts as \% of GDP.

During the last 7 years, a relatively low share of public revenues in GDP was accompanied by a systematic increase in tax liabilities. The problem of tax losses has existed in Poland at least since transformation. In the period of globalization, its importance is increased since it contributes to the new forms of tax fraud. Therefore, a tax gap is an interesting measure. According to Rimmer (2010), understanding the essence and idea of tax gap is a good starting point for finding the sources of tax income. The notion of tax gap means the difference between amount of tax which should be paid and amount of tax paid voluntarily and on time (Malamud and Parry, 2008, pp. 2-3). The size of this gap shows the loss in tax revenue (European Commission, 2016b, p. 14; Gencheva, 2010, p. 141). Among many countries estimating this measure is a part of monitoring and evaluation of compliance risk management strategies (OECD, 2015, p. 127). Polish tax authorities have not estimated the amount of tax gap so far.

Since 2007 VAT gap has been nearly systematically growing but by this year, the volume of the tax gap had been significantly decreasing and slightly exceeded PLN $2 \mathrm{bn}$. The share of VAT tax gap in the VTTL stabilised at 16\% on average. The loss of VAT revenues in most of the years exceeds tens of billions of PLN (which represents 2-3\% of the average annual GDP). In case of PIT gap we can observe that the amount oscillated about 11.5 bn PLN average (Klonowska, 2017). Hidden direct taxes represented 19\% of the total tax liabilities. That is indicative of poor tax discipline. Data presented in table 1 suggest that the impact of the recovered tax gap for both taxes could be important fiscal policy improvement.

Such approximate value of tax gap amount leads to one conclusion, the effectiveness of fiscal policy should be and could be higher. Fiscal authorities in Poland following the model of OECD countries should adopt the principle of continuous monitoring the size of the tax gap computed with identification of tax risk areas. The use of such a tool falls within broad reasoning of new public management and can prevent escalation of the problem.

\subsection{Public expenditure side}

Situation in public expenditure area was slightly different in comparison to the revenue side. The amount of public expenditures increased year-onyear throughout almost the whole period. Their rate of change, as in the case of revenue, was varied. To 2006, and in 2010, 2012 and 2014 to 2015 there was a much faster increase in expenditure than in other periods. Such a tendency is appropriate due to the activation of automatic economy stabilizers. In the years 2004-2009 public expenditure increased on average annual basis at a much faster rate than public revenues (4\%). However, in the period 2010-2015 this 
rate was reduced to $2 \%$. Thus, it has become slower in comparison with changes in public revenue (3.6\%) (Eurostat, 2017).

Public expenditures are used to evaluate the level of fiscalism in the country. With reference to GDP, it is defined as an allocation index. The average level of allocation index in Poland has been almost 44\% of GDP in period 2002-2015. On the one hand it was significantly lower in comparison to the first members of the EU (48\%) but on the other hand it was rather high level amongst new members (38\%) (Eurostat, 2017). It should be added that Poland is among the few EU countries in which the measure decreased in period 2010-2015. Fiscalism index decreased 1.5 p.p. It should be emphasized here that the issue of appropriate fiscalism level is connected with important topics, often described in the subject literature and concerning the role of fiscal policy in the pursuit of macroeconomic stability (Silva de Jesus \& Motta Correia, 2016). Next, economists also indicate: tax shifting (European Commission, 2016b), crowding out private spending by the public sector (Owsiak, 2014), fiscal-redistributive gap (Lubińska, 2011), and finally reducing the fiscal discipline (noncompliance) (Dubin, 2012).

Public expenditures in Poland are characterized by a high share of expenditures on social care. Nearly $17 \%$ of total expenditures is allocated for this purpose. The second aim of financing is: general public services and education (about 6\% average). The less amount is spent on environment protection ( $0.6 \%$ average). The implementation of an effective fiscal policy requires limiting expenditures on non-productive purposes. It is extremely important since the funds can be devoted to future-oriented areas, like economy, health etc. Only in 2003-2008 the amount of social expenditures slightly started to decline. Starting from 2010, we observe such changes only in few areas. There were three groups of expenditure: health; recreation, culture and religion; education. Health and education play crucial role in pursuing the objectives of fiscal policy amongst others. The allocation index is presented in table 2. Due to the lack of data the period covers 2002-2015.

On the expenditure side we can recognize other weak points. Public budget in Poland suffers from incorrect structure of public expenditure. Furthermore, the effects of the performance budgeting implemented in public sector in 2006 are doubtful. Simultaneously, the dissipation of public funds should be considered between various institutions of public finance sector.

Moreover, empirical research confirms that the structure of public budget is dominated by rigid expenditures. The Government can not freely regulate their amount contrary to flexible expenditures (for example remuneration in budget entities) which can be modified according to discretion of authorities. The major categories in group of rigid expenditures are as follows: servicing of public debt, subventions for units of local government, grants for public funds, expenses on defence, contribution to the EU budget. Statistical data proves that the share of rigid expenditures in public budget gradually increased. In $1999 \mathrm{r}$. it was 58\%. While in 2011 it was almost 75\% (Ministerstwo Finansów, 201la). Undoubtedly, 
the value of this group results from the aims on which they are intended. For instance, subventions for local government units finance public needs, mainly education. Every year about $50 \%$ of expenditures are intended for subventions and subsidies. Annually only about $5 \%$ is spent on capital expenditures, which reflect public investments. The cost of servicing the public debt is almost $12 \%$, and next to some grants and subsidies they are the rigid expenditures. More than $18 \%$ annually is spent on current needs, such as wages in the public sector. Subsidies are transferred mainly to state funds. The greatest recipient permanently is The Social Insurance Fund which in 2015 received 42 bn PLN, next to Agricultural Social Insurance Fund with amount of more than 17 bn PLN (Ministerstwo Finansów, 2015a, p. 205). Data are presented in table 3.

The high share of rigid expenditures in budget induces problems with adjusting the overall amount of expenditures to possible economic situation.

Summing up, consolidation, rationalization, flexibility and strengthening of public finance discipline influence public expenditures. Korniluk (2016), argues that the implementation of the stabilizing expenditure rule in 2014 changed restrictiveness and cyclicity of fiscal policy. The right direction is the use of cyclical review of public expenditure. It corresponds to the EU requirements in the application of numerical fiscal rules. Cyclical expenditure review supports intelligent fiscal consolidation. Its purpose is to increase the fiscal space to finance new assignments (Ministerstwo Finansów, 2015b; 2015c).

\section{Conclusions}

We can recognize at least a few negative system solutions which can limit achieving aims. Amongst them there are especially: high level of redistribution of GDP, no cyclical monitoring of the tax gap, as well as a high and growing share of fixed expenditures in the state budget. However, what is positive is that fiscal authorities in Poland undertake series of changes in both sides of the system. Empirical investigations show that Polish fiscal authorities have implemented (or, at least, have considered), different concepts and ideas that have long-lasting tradition in many other countries (Order of the Minister of Finance, 2015; Ministerstwo Finansów, 2014b).

Beginning from 2004 policymakers has worked on tools for recognizing the tax risk in a better way. In 2006 the process of implementation of performance budgeting was started. It was assumed that implementing the performance budgeting rules may affect limitation of public risk. The latest initiative is the consolidation of the treasury structures. It leads to improve the tax collection and the voluntary compliance.

Observation of practice suggests that reducing the barriers of fiscal policy effectiveness is enormously difficult, complicated, long term, but it is not impossible. Moreover, it is a challenge for policymakers. Undertaking specific arrangement of the system in a future perspective may replace the fiscal consolidation. 


\section{References}

Arestis, P., \& Sawyer, M. (2004). On the effectiveness of monetary policy and of fiscal policy. Review of Social Economy, 62(4). doi:10.1080/0034676 042000296218.

Auerbach, A., \& Gorodnichenko, Y. (2017). Fiscal stimulus and fiscal sustainability. NBER Working Paper, 23789. doi:10.3386/w23789.

Barrios, S., Langedijk, S., \& Pench, L. (2010). EU fiscal consolidation after the financial crisis. Lessons from past experience. European Economy. Economic Papers, 418. doi:10.2765/42879.

Carnot, N. (2014). Evaluating fiscal policy. A rule of thumb. European Economy. Economic Papers, 526. doi:10.2765/70540.

CASE. (2013). Study to quantify and analyse the VAT gap in the EU-27 member states. Retrieved 15.07.2018 from https://ec.europa.eu.

CASE. (2016). Study to quantify and analyse the VAT gap in the EU-28 member states. Retrieved 15.07.2018 from https://ec.europa.eu.

Chakraborty, L.S. (2016). Fiscal consolidation, budget deficit and the macro economy. Thousand Oaks: SAGE.

Christ, C.F. (1979). On fiscal and monetary policies and the government budget restraint. The American Economic Review, 69(4).

Collard, F., Habib, M., \& Rochet, J.C. (2015). Sovereign debt sustainability in advanced economies. Journal of the European Economic Association, 13(3). doi:10.1111/jeea.12135.

Corsetti, G., \& Müller, G. (2008). The effectiveness of fiscal policy depends on the financing and monetary policy mix. Retrieved 11.11.2008 from http://voxeu.org.

Dubin, J.A. (2012). The causes and consequences of income tax noncompliance. New York: Springer. doi:10.1007/978-1-4419-0907-7.

European Commission. (2016a). Taxation trends in the European Union. Data for the EU member states, Iceland and Norway: 2016 edition. doi:10.2785/751842.

European Commission. (2016b). The concept of tax gaps: report on VAT gap estimations. Retrieved 15.07.2018 from https://ec.europa.eu.

Eurostat. (2017). Retrieved 25.01.2017 from http://ec.europa.eu/eurostat.

Friedman, M., \& Heller, W.W. (1969). Monetary vs fiscal policy. New York: W.W. Norton \& Company.

Gaspar, V. (2016). Fiscal policy for the twenty-first century: testing the limits of the tax state? In O.J. Blanchard, R.G. Rajan, K.S. Rogoff, \& L.H. Summers (Eds.), Progress and confusion: the state of macroeconomic policy. London: MIT Press.

Gencheva, V. (2010). Tax gap in Bulgaria: first attempt. Tax Tribune, 27.

GUS. (2017). Retrieved 25.01.2017 from http://stat.gov.pl.

Hebous, S. (2010). The effects of discretionary fiscal policy on macroeconomic aggregates: a reappraisal. Journal of Economic Surveys, 25(4). doi:10.1111/j.1467-6419.2010.00659.x. 
Hemming, R., Kell M., Mahfouz S. (2002). The effectiveness of fiscal policy in stimulating economic activity: a review of literature. IMF Working Paper, 02(208). doi:10.5089/9781451874716.001.

Karaca, C., \& Ugurlu, E. (2014). Measurement of efficiency of fiscal policies implemented for global crisis: did Turkey have success in crisis management? Journal of Human Siences, 11(1). doi:10.14687/ijhs.vllil.2867.

Kickert, W.J.M., Randma-Liiv, T., \& Savi, R. (2015). Politics of fiscal consolidation in Europe: a comparative analysis. International Review of Administrative Sciences, 81(3). doi:10.1177/0020852314564312.

Klonowska, A. (2017). Luka podatkowa. Skutki dla finansów publicznych. Warszawa: C.H. Beck.

Kofuji, Y. (1984). On the efficacy of fiscal policy and price level changes. Public Finance Review, 12(2). doi:10.1177/109114218401200203.

Konopczyński, M. (2012). Wpływ opodatkowania na wzrost gospodarczy. Ekonomista, 6.

Korniluk, D. (2016). The stabilizing expenditure rule in Poland: simulations for 2014-2040. Eastern European Economics, 54(4). doi:10.1080/00128775.201 6.1180252 .

Krajewski, P. (2015). Effectiveness of fiscal policy in stimulating economy: the case of Poland. Transformations in Business and Economics, 14(2).

Kuttner, K.N., \& Posen, A.S. (2002). Fiscal policy effectiveness in Japan. Journal of the Japanese and International Economies, 16(4). doi:10.1006/ jjie.2002.0512.

Lubińska, T. (2011). Pożądane kierunki i scenariusze naprawy finansów publicznych w Polsce. In A. Pomorska, \& J. Szołno-Koguc (Eds.), Ekonomiczne i prawne uwarunkowania i bariery redukcji deficytu i dtugu publicznego. Warszawa: Wolters Kluwer.

Malamud, R.B., \& Parry, R.O. (2008). It's time to do something about the tax gap. Houston Business and Tax Law Journal, 9(1).

Mandl, U., Dierx, A., \& Ilzkovitz, F. (2008). The effectiveness and efficiency of public spending. European Economy. Economic Papers, 301. doi:10.2765/25272.

Ministerstwo Finansów. (2000a-2015a). Sprawozdanie z wykonania budżetu państwa w latach 2000-2015. Retrieved 15.07.2018 from https://www. mf.gov.pl.

Ministerstwo Finansów. (2014b). Działania zwiększające stopień przestrzegania przepisów podatkowych i poprawiające efektywność administracji podatkowej w latach 2014-2017. Retrieved 15.07.2018 from https://www.mf.gov.pl.

Ministerstwo Finansów. (2015b). Analiza elastyczności wydatków budżetowych w Polsce. Podsumowanie wyników wspótpracy z OECD. Retrieved 15.07.2018 from https://www.mf.gov.pl.

Ministerstwo Finansów. (2015c). Przegląd wydatków publicznych: cele, metodyka, organizacja. Retrieved 15.07.2018 from https://www.mf.gov.pl. 
Ministerstwo Finansów. (2016b). Wieloletni plan finansowy państwa na lata 20162019. Retrieved 15.07.2018 from https://www.mf.gov.pl.

Ministerstwo Finansów. (2017). Retrieved 25.01.2017 from https://www.finanse.mf.gov.pl.

OECD. (2015). Tax administration 2015. Comparative information on OECD and other advanced and emerging economies. Retrieved 15.07.2018 from https://www.oecd-ilibrary.org.

Owsiak, S. (2006). Finanse publiczne. Teoria i praktyka. Warszawa: PWN.

Owsiak, S. (2014). Kontrowersje wokół wypierania dochodów z gospodarki przez finanse publiczne. In J. Czekaj, \& S. Owsiak (Eds.), Finanse w rozwoju gospodarczym i spotecznym. Warszawa: PWE.

Poindexter, J.C. (1976). Macroeconomics. Hinsdale: The Dryden Press.

Potrafke, N., \& Reischmann, M. (2015). Fiscal transfers and fiscal sustainability. Journal of Money, Credit \& Banking, 47(5). doi:10.1111/jmcb.12231.

Rimmer, D. (2010). Closing the tax gap. Retrieved 23.08.2013 from http:// www.epma.cz.

Seidman, L.S. (2003). Automatic fiscal policies to combat recessions. New York: Routledge. doi:10.4324/9781315706245.

Silva de Jesus, C., \& Motta Correia, F. (2016). Active fiscal policy and macroeconomic stability. Journal of Economic Studies, 43(5). doi:10.1108/ JES-03-2015-0052.

Stoian, A., \& Campeanu, E. (2010). Fiscal policy in the short term for assessing fiscal sustainability in the long run in central and eastern European Union countries. Czech Journal of Economics and Finance, 60(6).

Żabiński, A. (2010). Fiscal instruments for reaching economic goals in Central and Eastern Europe. Transformations in Business and Economics, 9(2).

Zarządzenie Nr 30 Ministra Finansów z dnia 4 maja 2015 r. w sprawie powołania Komitetu Sterującego do spraw przeglądów wydatków publicznych [Order No 30 of the Minister of Finance of 4 May 2015 on the formation of the Steering Committee for the overview of public expenditure] (Dz. Urz. Min. Fin. poz. 31) (Poland).

\section{Acknowledgements}

Author contributions: author has given an approval to the final version of the article.

Funding: this research was fully funded by the Cracow University of Economics, Faculty of Finance and Law sources (005 WFP-KF/01/2017/S/7005).

Note: the results of this study were presented in another form, such as abstract at 9th International Conference on Applied Economics Contemporary Issues in Economy (June 22-23, Torun, Poland). 


\section{Appendix}

Table 1.

Tax gap for Value Added Tax and Personal Income Tax in Poland in 2000-2014*

\begin{tabular}{lcccc}
\hline Period & VAT gap (in mln PLN) & VAT gap / VTTL (in \%) & PIT gap (in mln PLN) & PIT gap / TTL (in \%) \\
\hline 2000 & 2606 & 16.8 & - & - \\
2001 & 3803 & 20.9 & - & - \\
2002 & 3370 & 18.3 & - & - \\
2003 & 2908 & 17.5 & 9412 & 25.8 \\
2004 & 2977 & 16.9 & 6068 & 17.1 \\
2005 & 1916 & 9.2 & 7285 & 17.3 \\
2006 & 1211 & 5.2 & 6514 & 13.0 \\
2007 & 511 & 1.9 & 10136 & 16.6 \\
2008 & 2743 & 8.6 & 13214 & 19.1 \\
2009 & 3985 & 14.7 & 12243 & 19.1 \\
2010 & 7135 & 20.6 & 12694 & 19.8 \\
2011 & 7840 & 20.9 & 18354 & 24.7 \\
2012 & 9790 & 26.1 & 11643 & 16.5 \\
2013 & 9447 & 25.4 & 11684 & 15.8 \\
2014 & 9301 & 24.1 & 18099 & 21.3 \\
\hline
\end{tabular}

Notes:

* - the data converted at the average exchange rate of 10.12.2017. It takes into account the change in the system of national accounts;

VTTL — Voluntary Theoretical Tax Liability.

Source: Own preparation based on CASE (2013, p. 116, 122; 2016, p. 64, 69, 70). 


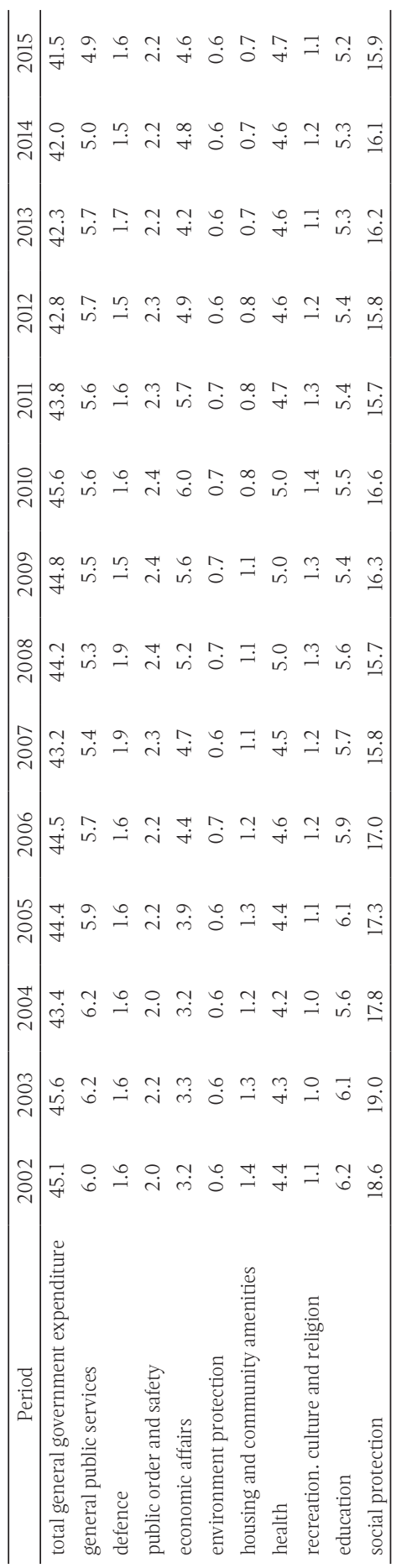

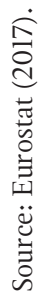




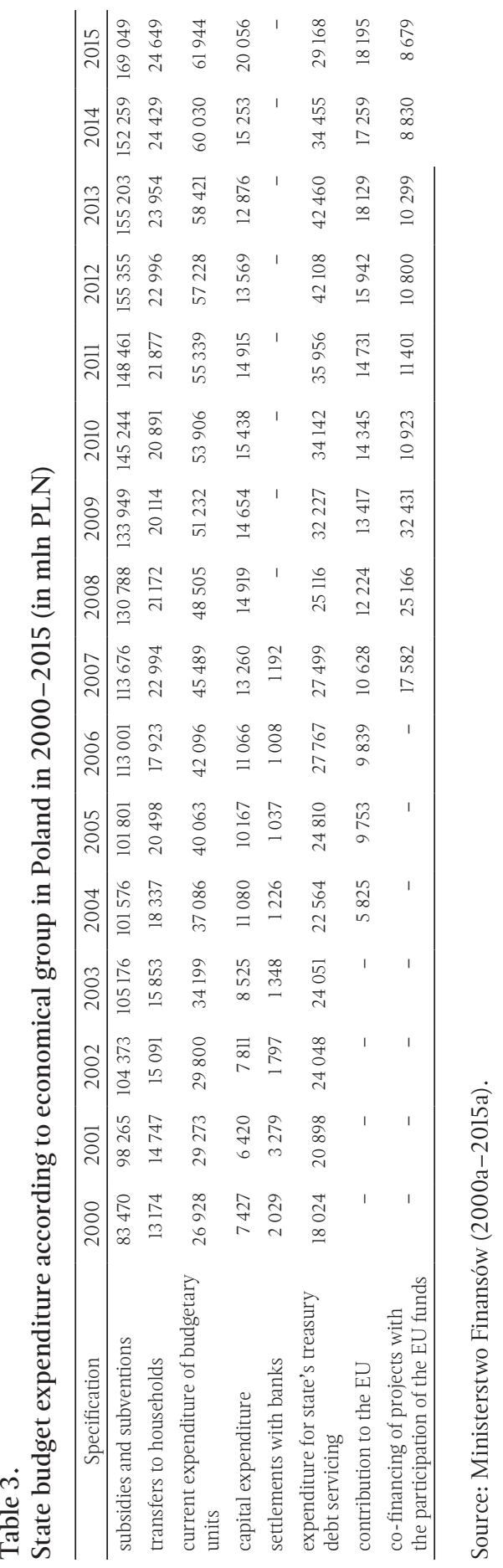




\section{Chart 1.}

Macroeconomic indicators in Poland in 2000-2015 (in \% of GDP)

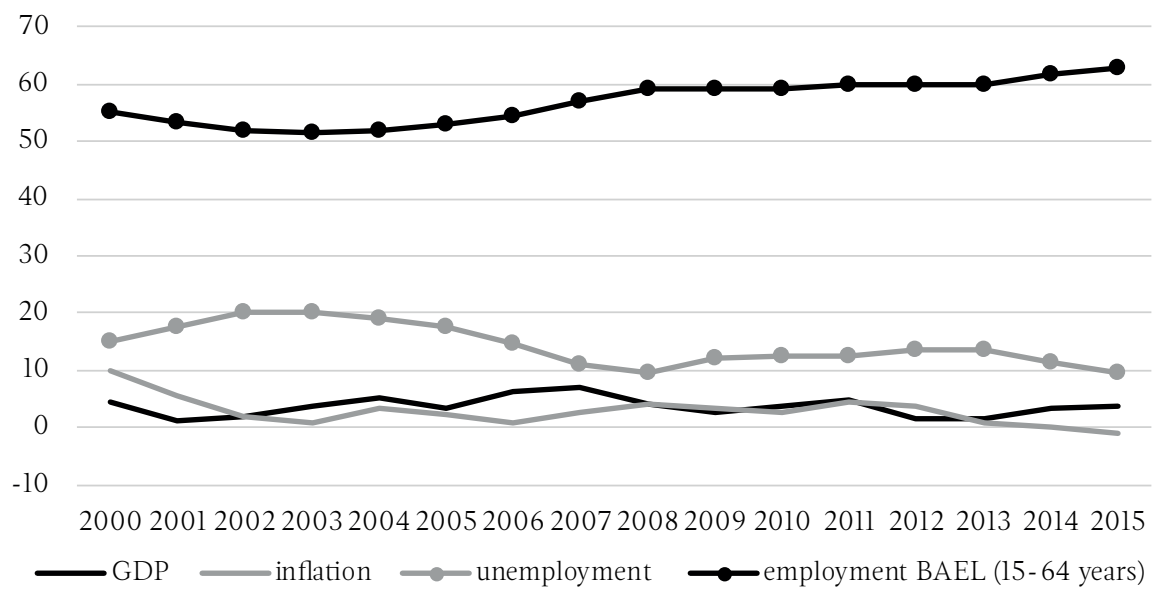

Source: GUS (2017).

\section{Chart 2.}

Deficit budget and public debt in Poland in 2000-2015 (in \% of GDP)

1

$$
0
$$

0

$-1$

$-2$

$-3$

$-4$

$-5$

$-6$

2000200120022003200420052006200720082009201020112012201320142015 deficit budget (left scale)

Source: GUS (2017). 
Chart 3.

Fiscalism index in Poland in 2000-2015 (in \% of GDP)

45

40

35

30

25

20

15

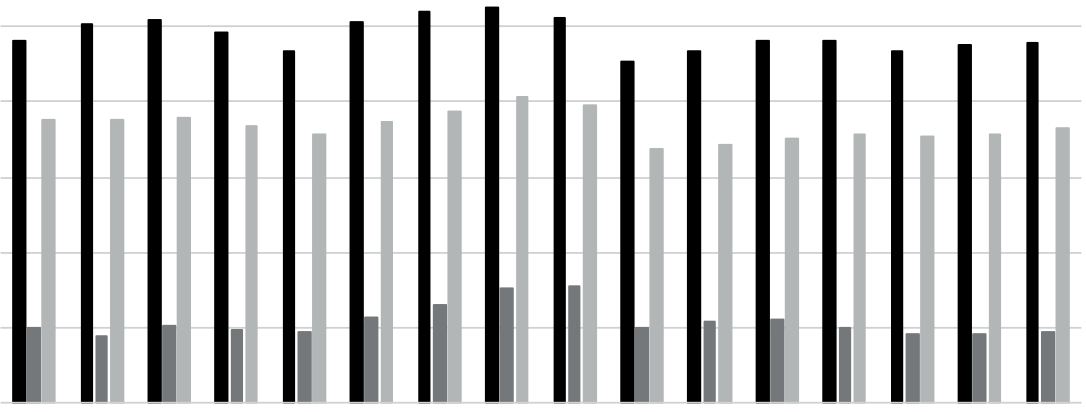

2000200120022003200420052006200720082009201020112012201320142015

- public revenues total tax receipts total receipts from taxes and social contributions*

Note:

* - including imputed social contributions, after deductions of amounts assessed but unlikely to be collected.

Source: Eurostat (2017).

Chart 4.

Tax debts in Poland in 2000-2015

70

4,0

60

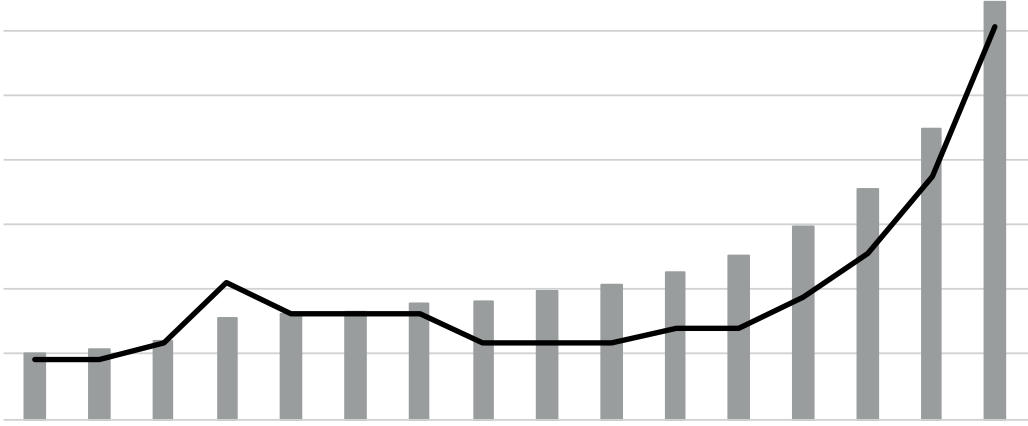

3,5

3,0

40

2,5

2,0

20

0

2000200120022003200420052006200720082009201020112012201320142015

tax debts (in bln PLN)

— tax debts (in \% of GDP)

Source: Ministerstwo Finansów (2017) and GUS (2017). 
